\title{
Lifestyle-Determined Gender and Hierarchical Differences in the Lead Contamination of Bones from a Feudal Town of the Edo Period
}

\author{
Tamiji Nakashima ${ }^{1}$, Kohji Matsuno ${ }^{2}$ and Takayuki Matsushita ${ }^{3}$
}

${ }^{1}$ The First Department of Anatomy, School of Medicine, ${ }^{2}$ Bio-information Research Center, University of Occupational and Environmental Health, Japan and ${ }^{3}$ The Doi-ga-hama Site, Anthropological Museum, Japan

\begin{abstract}
Lifestyle-Determined Gender and Hierarchical Differences in the Lead Contamination of Bones from a Feudal Town of the Edo Period: Tamiji NaKashima, et al. Department of Anatomy, University of Occupational and Environmental Health, Japan-We analyzed lead concentrations in bones from both genders of Japanese merchants (including rohnin; masterless samurai) and farmer classes, and compared the findings with those of the samurai class in the Edo period (1603-1867) to clarify gender and hierarchical (or occupational) differences in lead exposure during the Japanese feudal age. Merchant class females had significantly higher lead exposure (90.8 $\mu \mathrm{g} \mathrm{Pb} / \mathrm{g}$ dry bone; $\mathrm{n}=20)$ than males of the same class $(39.9 \mu \mathrm{g} \mathrm{Pb} / \mathrm{g}$ dry bone; $\mathrm{n}=31)(p<0.01)$, indicating a remarkable gender difference in the urban population. In contrast to these high concentrations, males and females of the farmer class living in agricultural (or semi-rural) areas had significantly lower exposure (total mean value; $9.2 \mu \mathrm{g} \mathrm{Pb} / \mathrm{g}$ dry bone; $\mathrm{n}=4$ ) than both genders of the merchant class $(p<0.001)$, and the gender difference was not significant in this class.
\end{abstract}

(J Occup Health 2007; 49: 134-139)

Key words: Gender and hierarchical differences, Lead contamination of human bones, Edo period, Lifestyle, Aristocratic characteristics

Since Japanese modernization began in 1868 (Meiji Reformation), lead ( $\mathrm{Pb}$ ) pollution in our overall environment has greatly increased, especially with industrialization, urbanization and motorization ${ }^{1-3)}$. Before that, Japan was an agricultural country ruled by

Received Sep 11, 2006; Accepted Dec 25, 2006

Correspondence to: T. Nakashima, Department of Anatomy, School of Medicine, University of Occupational and Environmental Health, Japan, Kitakyushu city, Fukuoka 807-8555, Japan

(e-mail:tnakash@med.uoeh-u.ac.jp) samurai warriors during the Edo period (1603-1867). The Edo period, also called the Tokugawa period, is often dated from 1603, when Tokugawa Ieyasu received the title of Shogun from the Emperor. He established the Tokugawa Shogunate in the town of Edo (present day Tokyo), and it continued until 1867 when the last Shogun resigned and restored the reins of government to the Emperor. One of the major epochs in Japanese history, the Edo period is distinguished by the fact that for more than two centuries (from 1638 to 1864) Japan enjoyed freedom from warfare at home and abroad. About 400 years ago, people lived under less polluted conditions than the contemporary atmosphere and environment in Japan; however, we reported that an extremely polluted population lived in a castle town in Japan in that less contaminated and peaceful period ${ }^{4}$. They were a feudal lord family and their retainers. The family name of the daimyo (feudal lord) in Kokura, Kitakyushu city was Ogasawara. The Ogasawara family ruled Kokura from 1632 (when Ogasawara entered Kokura) to 1866 (when Kokura was burned down by the Choshu clan). Ogasawara was a fudai daimyo, that is, one of Tokugawa's loyal retainers, who kept watch over the other daimyo in Kyushu and Yamaguchi (Fig. 1). As Kokura was along a commercial route and was strategically important, this castle town prospered greatly. Each daimyo built at the center of his domain a castle headquarters in which his samurai retainers were housed, necessitating the assembling of services, merchants, carpenters, artisans and the like, to meet the needs of the assembled samurai. By the end of the 19th century, Edo, the greatest of the castle towns, had a population of nearly one million. Osaka and Kyoto each had some 300,000 inhabitants and Kokura had almost 14,000 in 1845.

In a previous study, we analyzed the lead concentrations in bones from both genders of the samurai class (Ogasawara family and their retainers) and compared the findings with those of farmer and fishermen classes 

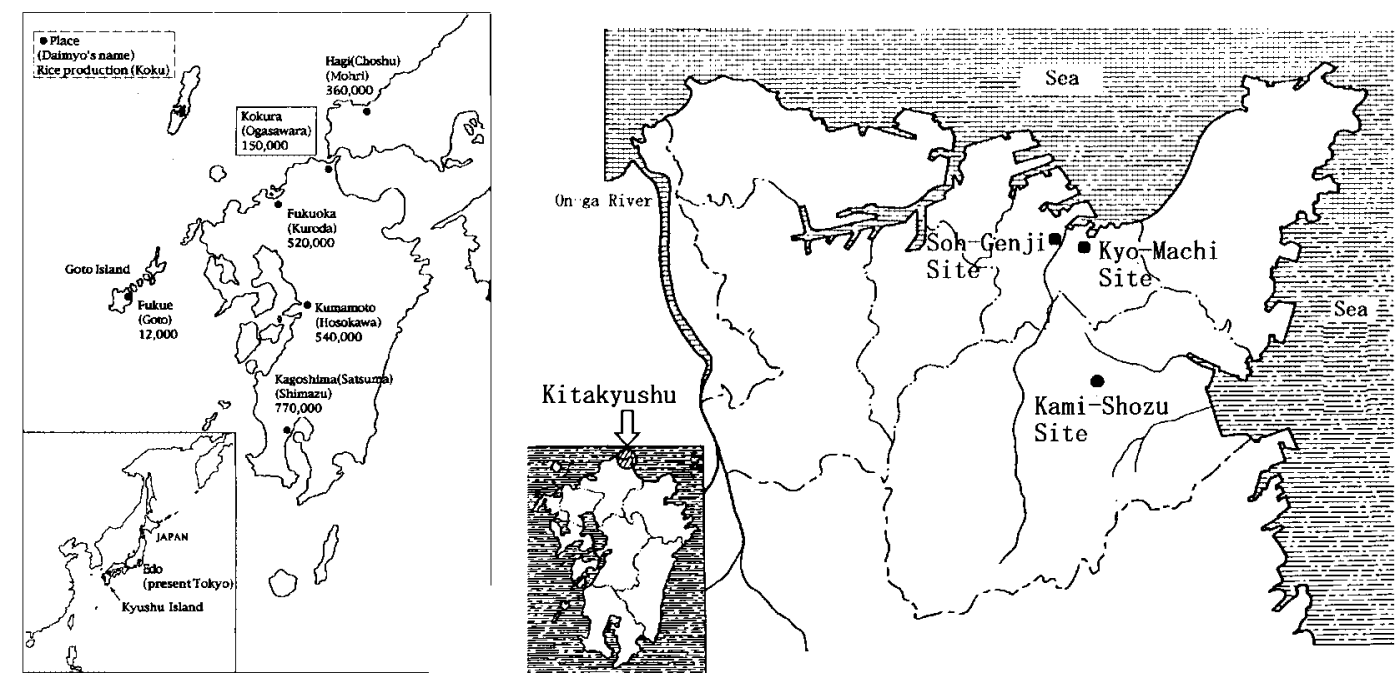

Fig. 1. Left: Main daimyo (feudal lords) of western Japan during the Edo period (1603-1867). • : Place, name of daimyo, rice production $(k o k u)$ are shown. One koku equals about $180 \mathrm{l}$. Right: The remains of the Ogasawara clan and their feudal estates, situated in Kitakyushu city, Japan.

(people living in very rural areas far from Kokura) in the Edo period ${ }^{4}$. In this study, we analyzed lead concentrations in bones from both genders of the merchant (including rohnin) and farmer classes living within Ogasawara's feudal domain in the Edo period. They were ruled by the Ogasawara family and their retainers in Kokura (present day Kitakyushu city).

\section{Materials and Methods}

For our study we selected rib samples from merchant class and farmer class remains of the Edo period (Table 1). Bone samples from the merchant class consisted of ribs excavated from the Kyo-Machi site ${ }^{5)}$. The burial methods at this site consisted of interment (male-a) and burial pods (male-b). The latter might have been rohnin (masterless samurai). Rohnin lived among the merchant class while searching for new forms of employment. Farmer class samples were excavated at the Kami-Shozu site $^{6)}$ and were all buried in a mound. To compare merchant and farmer classes, the mean values of a previous study ${ }^{4}$ were used. These were samurai (Sohgenji site $^{7)}$ ) and farmer and fisherman (Tohgashima Shirahama site ${ }^{8)}$, called Goto Island site for short, a rural area about $200 \mathrm{Km}$ south west from Kokura) classes.

Bone samples were treated with $1 \% \mathrm{NaOH}$ and then were dried at $105^{\circ} \mathrm{C}$ for $24 \mathrm{~h}$. Approximately $200 \mathrm{mg}$ of rib bone was taken and the precisely weighed sample was transferred into a $100-\mathrm{m} l$ Kjeldahl flask and digested with a mixture of $15 \mathrm{~m} l$ nitric acid and $2 \mathrm{~m} l$ sulphuric acid. The residual sample was made up to $100 \mathrm{~m} l$ with distilled water. The sample solution was analyzed by atomic absorption spectrometry, with a Hitachi Model
$180-80$ spectrometer equipped with a graphite atomizer. The concentration of the sample was calculated from the calibration curve derived from standard solutions for each run.

\section{Results}

Mean lead values of males and females in the merchant and farmer classes are shown in Table 1. For comparison with these values, previously reported data ${ }^{4)}$, the mean values of samurai (ruler class of Kokura domain) and farmer and fishermen classes (excavated at Goto Island) have been added to this table. The male mean $(n=31)$ was $39.9 \mu \mathrm{g} \mathrm{Pb} / \mathrm{g}$ dry bone and the female $(\mathrm{n}=20)$ was $90.8 \mu \mathrm{g} \mathrm{Pb} / \mathrm{g}$ dry bone in the merchant class. In the farmer class, the male value $(\mathrm{n}=1)$ was $4.9 \mu \mathrm{g} \mathrm{Pb} / \mathrm{g}$ dry bone and the female value $(\mathrm{n}=1)$ was $10.4 \mu \mathrm{g} \mathrm{Pb} / \mathrm{g}$ dry bone. The total mean value of the farmer class $(n=4)$ was $9.2 \mu \mathrm{g}$ $\mathrm{Pb} / \mathrm{g}$ dry bone. Male and female mean lead values in the merchant class were significantly higher than the mean lead values of the farmer class $(p<0.001)$. In the merchant class, the female lead value was significantly higher than that of the male $(p<0.01)$, but it was not significantly different in the farmer class. A significant gender difference in lead concentrations was seen in the merchant class (urban population), but not in the farmer class (semirural population). These tendencies were also seen in the samurai class (urban population) and farmer and fisherman classes (rural population) in the previous study ${ }^{4}$. Males and females of the merchant class had significantly higher lead values than both genders of the samurai class (male; $p<0.001$, female; $p<0.01$ ). Furthermore, male and female mean lead values in farmer 
Table 1. Lead concentrations in rib bones from the Kyo-Machi site and Kami-Shozu site compared with those from Sohgenji site and Goto Island site

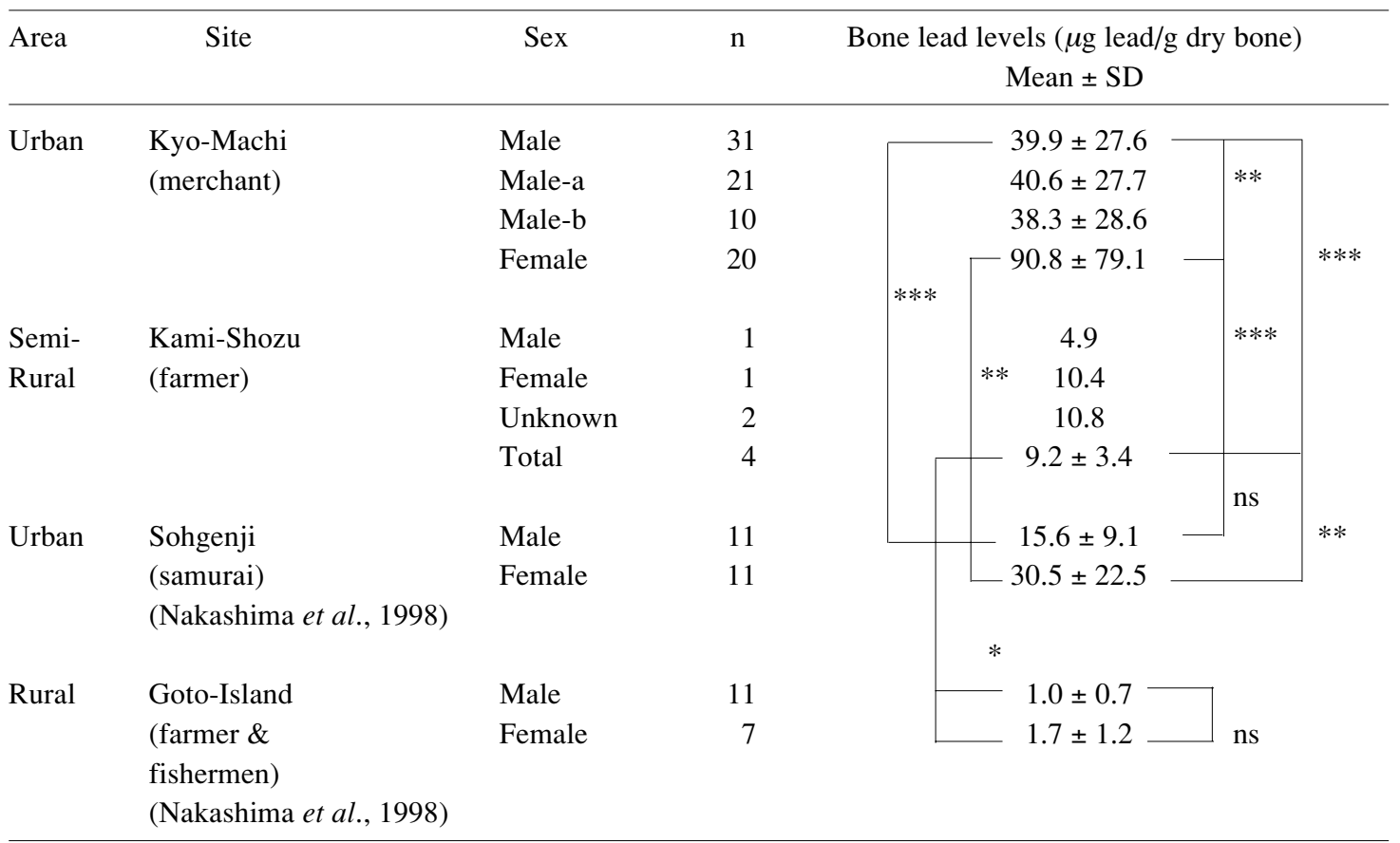

significant: $* * * p<0.001, * * p<0.01, * p<0.05$, ns: not significant

The burial method at the Kyo-Machi site consisted of interment (male-a) and burial pods (male-b). All female remains were found in a burial mound. The remains excavated at the Kami-Shozu site were all from a burial mound.

and fisherman classes (Goto Island site; rural population) were significantly lower than the mean value of the farmer class (semi-rural population) $(p<0.05)$.

\section{Discussion}

Lead, atomic number 82 , is one of the most abundant non-essential trace elements in the human body. Bone contains approximately $91 \%$ of the total body burden of $\operatorname{lead}^{9)}$. The lead level in human beings is measured by blood lead and bone lead concentrations. The blood lead level is recognized as an inadequate index of lead exposure and accumulation in populations, because it captures only a short time frame of previous exposure limited to 21-30 $\mathrm{d}^{10)}$. Lead concentrations in the bone constantly increase with age in both sexes. The analysis of lead in bone specimens can be used to monitor lead contamination in human being ${ }^{11-28)}$. In this paper, we intended to evaluate the total amount of lead exposure and accumulation in populations using human bones excavated at archeological sites, however, a confounding problem is that bones are exposed to post-mortem absorption of lead in the ground ${ }^{29-31)}$. In the Japanese burial service, coffins were usually made of wood and pottery as an uncolored earthen pod, and the face of the dead person was not painted heavily. The lead concentration of soil at the Sohgenji site was $21.7 \mu \mathrm{g} \mathrm{Pb} /$ g dry weight, and the Kyo-Machi site was a few hundred meters from that site. Both sites were in the same town. Judging from the lead concentration of the soil in the urban area, diagenesis was not considered to be responsible for the extremely high concentrations of lead found in the urban populations.

Merchant class people had extremely high lead contamination in the Edo period. Although Kosugi et $a l .{ }^{32,33)}$ described the people of the city of Edo (present day Tokyo) as highly polluted by environmental lead, we suggest that the lead contamination was not caused by environmental lead but by luxury goods peculiar to females which contained lead, as lead contamination was seen only in the merchant and samurai classes, and gender differences were seen in both classes. In that period, rulers and rich people lived in castle towns, and they enjoyed an urban lifestyle. As the largest castle town was Edo (present day Tokyo) in the Edo period, the tendency seen in Kokura might be more remarkable in people living in the principal city of Japan in the Edo period.

We assume that facial cosmetics were one of the main sources of lead exposure for urban people compared to the farmer class in rural areas, who were prohibited from using luxury goods by law (decree), because they were rice production workers. The manufacture and use of 

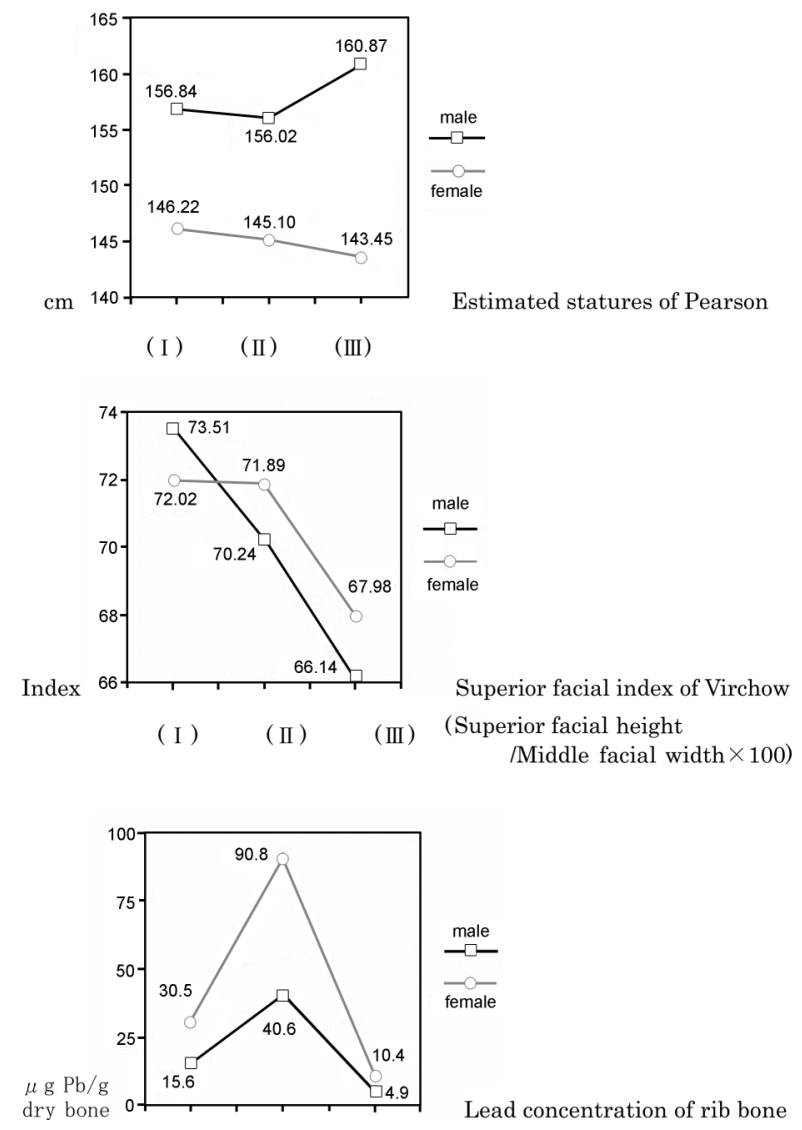

( I ) (II) (III)

Fig. 2. Physical anthropological features of the people and lead concentrations of rib bones found at the three sites. (I): Sohgenji site, (II): Kyo-Machi site, (III): Kami-Shozu site.

face powder, rouge, eyebrow paint and other cosmetics were introduced into Japan from Korea and China. During the Edo period, cosmetics became popular and the vogue was usually introduced by kabuki actors, courtesans, and geisha through woodblock prints (ukiyo$e$ ) and popular literature, and by beauticians who helped set fashion. White face powders used in those days were made from keifun (mercury chloride) and empaku (white lead). Mercury chloride was mainly imported from China, and white lead was popular in Japan, although the toxic nature of lead cosmetics was not recognized.

The populations compared in our study were merchant (Kyo-Machi site), farmer (Kami-Shozu site), samurai (Sohgenji site), farmer and fisherman (Goto Island site) classes. In the Edo period, people were isolated by differences in social status. The samurai class was the elite and they ruled in each region. The Tokugawa Shogunate was at the top of the samurai class. The physical characteristic of the Tokugawa Shoguns was their faces, which were exceptionally high and narrow with

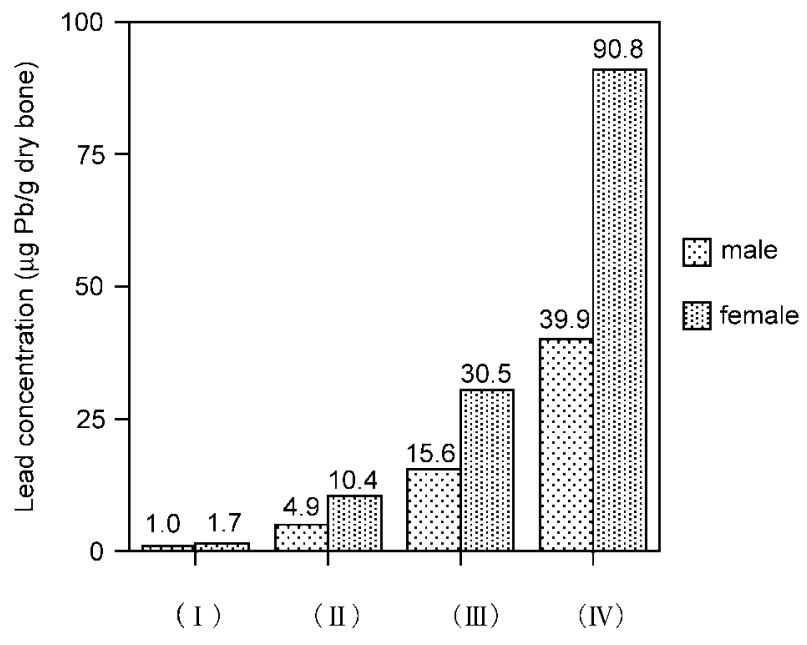

Fig. 3. Lead concentrations of rib bones of all populations. (I): Goto Island site,(II): Kami-Shozu site, (III): Sohgenji site, (IV): Kyo-Machi site.

an extremely narrow and prominent nose, high and roomy orbit (eyehole), and highly reduced upper and lower jaws. These characteristics were therefore regarded as aristocratic features ${ }^{34)}$. The samurai class in the Kokura domain had an extremely high and narrow face compared with the merchant and farmer classes in the same domain, as shown in Fig. 2. The superior facial indices of the Virchow (Fig. 2; middle) Index were calculated by the formula: Superior facial height/Middle facial width $\times 100$. They were 73.51 (male) and 72.02 (female) in the samurai class. The same indices of the Tokugawa Shoguns and other daimyo were between 72.4 and 89.1. The indices of the merchant class were 71.89 (male) and 70.24 (female). These were not extremely low values compared with the farmer class (male; 67.98, female; 66.14). On the contrary, the values of the merchant class were closer to those of the samurai class. The aristocratic tendency seen in the samurai class was similar to the Tokugawa Shoguns' aristocratic features, but this tendency of the merchant class was not the same as in the samurai class because they were ordinary people. The superior facial indices of the merchant class were lower than that of the samurai class, but higher than that of the farmer class. These different characteristics might not have been caused by genetic factors but by differences in everyday life, that is, differences in lifestyle. Urban life was spent in the castle town, Kokura, and the facial characteristics of merchant class people were apparently different from those of farmer class people who had a semi-rural lifestyle and were prohibited from using luxury goods by law (decree). The lead concentrations of the rib bones of all the populations are shown in Fig. 3. Lead concentrations in farmer and fisherman classes, Goto Island site (rural lifestyle), showed the lowest values and the merchant 
class, Kyo-Machi site (urban lifestyle) showed the highest values. The lead contamination found in human bones of the Edo period may have been caused by lifestyle.

Acknowledgments: In this paper, we used data which were reported in the Journal of Occupational Health 1998: 40; 55-60. These are data of Table 2, Fig. 1 and p59; line 47-49, "the lead concentration in the soil in Sohgenji Temple Site (21.7 $\mu \mathrm{g} \mathrm{Pb/g} \mathrm{dry} \mathrm{weight)".} \mathrm{Article}$ reproduction of these data were permitted by the editorial office of the Journal of Occupational Health.

\section{References}

1) Murozumi M, Chow TJ and Patterson C: Chemical concentrations of pollutant lead aerosols, terrestrial dusts and sea salts in Greenland and Antarctic snow strata. Geochimica et Cosmochimica Acta 33, 12471294 (1969)

2) Thomas HV, Milmore BK, Heidbreder GA and Kogan BA: Blood lead of persons living near freeways. Arch Environ Health 15, 695-702 (1967)

3) Tsuchiya K, Sugita M, Seki Y. Study of lead concentrations in atmosphere and population in Japan. In: Griffin TB, Knelson JH, eds. Lead. Stuttgart: Georg Thieme, 1975: 95-146.

4) Nakashima $T$, Hayashi $H$, Tashiro $H$ and Matsushita $T$ : Gender and hierarchical differences in leadcontaminated Japanese bone from the Edo period. J Occup Health 40, 55-60 (1998)

5) Matsushita T. Medieval human bones excavated from Kyo-Machi site in Kitakyushu city. In: Kitakyushu City Education and Culture Organization, ed. Kitakyushu city excavation report no.59 Kyo-Machi site. Kitakyushu: Kitakyushu City Foundation for Promoting Arts and Culture, 1993: 177-248 (in Japanese).

6) Matsushita T. Medieval human bones excavated from Kami-Shozu site in Kitakyushu city. In: Kitakyushu City Education and Culture Organization, ed. Kitakyushu city excavation report no. 290 Kami-Shozu site. Kitakyushu: Kitakyushu City Foundation for Promoting Arts and Culture, 2003: 53-66 (in Japanese).

7) Matsushita T. Medieval human bones excavated from Sohgenji site in Kitakyushu city. In: Kitakyushu City Education and Culture Organization, ed. Kitakyushu city excavation report no.172 Sohgenji Site. Kitakyushu: Kitakyushu City Foundation for Promoting Arts and Culture, 1995: 502-542 (in Japanese).

8) Matsushita T. Medieval human bones excavated from TohgaShima Shirahama site in Arikawa town, Nagasaki prefecture. In: Arikawa town excavated report no. 1 TohgaShima Shirahama site. Nagasaki: Nagasaki Prefectural Board of Education, 1996: 67-87 (in Japanese).

9) Schroeder HA and Tipton IH: The human body burden of lead. Arch Environ Health 17, 965-978 (1968)

10) Rosen JF, Crocetti AF, Balbi K, Balbi J, Bailey C, Clemente I, Redkey N and Grainger S: Bone lead content assessed by L-line x-ray fluorescence in leadexposed and non-lead-exposed suburban populations in the United States. Proc Natl Acad Sci USA 90, 2789 2792 (1993)

11) Aufderheide AC, Neiman FD, Wittmers LE and Rapp G: Lead in bone II: Skeletal-lead content as an indicator of lifetime lead ingestion and the social correlates in an archaeological population. Am J Phys Anthrop 55, 285-291 (1981)

12) Aufderheide AC, Angel JL, Kelley JO, Outlaw AC, Outlaw MA, Rapp G and Wittmers LE: Lead in Bone III. Prediction of social correlates from skeletal lead content in four colonial American populations (Catoctin Furnace, College Landing, Governor's Land, and Irene Mound). Am J Phys Anthrop 66, 353-361 (1985)

13) Barry PSI: A comparison of concentrations of lead in human tissues. Brit J Indust Med 32, 119-139 (1975)

14) Ericson JE, Shirahata H and Patterson CC: Skeletal concentrations of lead ancient Peruvians. New Eng J Med 300, 946-951 (1979)

15) Gilfillan SC: Lead poisoning and the fall of Rome. J Occup Med 7, 53-60 (1965)

16) Grandjean P and Holma B: A history of lead retention in the Danish population. Environ Physiol Biochem 3, 268-273 (1973)

17) Grandjean P: Ancient skeletons as silent witnesses of lead exposures in the past. CRC Critical Reviews in toxicology 19, 11-21 (1988)

18) Hisanaga A, Eguchi Y, Hirata M and Ishinishi N: Lead levels in ancient and contemporary Japanese bones. Biol Trace Element Res 16, 77-85 (1988)

19) Hisanaga A, Hirata $M$, Tanaka $A$, Ishinishi $N$ and Eguchi Y: Variation of trace metals in ancient and contemporary Japanese bones. Biol Trace Element Res 22, 221-231 (1989)

20) Hofreuter DH, Catcott EJ, Keenan RG and Xintaras $\mathrm{C}$ : The public health significance of atmospheric lead. Arch Environ Health 3, 568-574 (1961)

21) Jawarowski Z: Stable lead in fossil ice and bones. Nature 217, 152-153 (1968)

22) Lambert JB, Vlasak SM, Thometz AC and Buikstra JE: A comparative study of the chemical analysis of ribs and femurs in Woodland populations. Am J Phys Anthrop 59, 289-294 (1982)

23) Mackie A, Townshend A and Waldron HA: Lead concentrations in bones from Roman York. J Archaeol Sci 2, 235-237 (1975)

24) Needleman HL, Tuncay OC and Shapiro IM: Lead levels in deciduous teeth of urban and suburban American children. Nature 235, 111-112 (1972)

25) Needleman HL, Davidson I, Sewell EM and Shapiro IM: Subclinical lead exposure in Philadelphia schoolchildren, identification by dentine lead analysis. New Engl J Med 290, 245-248 (1974)

26) Patterson CC: Contaminated and natural lead environments of man. Arch Environ Health 11, 344$360(1965)$

27) Szpunar CB, Lambert JB and Buikstra JE: Analysis of excavated bone by atomic absorption. Am J Phys Anthrop 48, 199-202 (1978) 
28) Wittmers LE, Wallgren J, Alich A, Aufderheide AC and Rapp G: Lead in bone. IV. Distribution of lead in the human skeleton. Arch Environ Health 43, 381-391 (1988)

29) Ghazi AM, Reinhard KJ, Holmes MA and Durrance E: Brief Communication: further evidence of lead contamination of Omaha Skeletons. Am J Phys Anthrop 95, 427-434 (1994)

30) Reinhard KJ and Ghazi AM: Evaluation of lead concentrations in 18th-century Omaha Indian skeletons using ICP-MS. Am J Phys Anthrop 89, 183-195 (1992)

31) Waldron HA: Postmortem absorption of lead by the skeleton. Am J Phys Anthrop 55, 395-398 (1981)
32) Kosugi H, Hanihara K, Suzuki T, Himeno S, Kawabe T, Hongo T and Morita M: Elemental composition of ancient Japanese bones. Sci Total Environ 52, 93-107 (1986)

33) Kosugi H, Hanihara K, Suzuki T, Hongo T, Yoshinaga $\mathrm{J}$ and Morita M: Elevated lead concentrations in Japanese ribs of the Edo era (300-120 BP). Sci Total Environ 76, 109-115 (1988)

34) Suzuki H: Manifestation of the physical characteristics of Japanese aristocrats in the Edo era of Japan. J Anthrop Soc Nippon 93, 1-32 (1985) (in Japanese with English summary) 